Snežana Golubović,

UDK: 902.2:572.7(497.11);

904:726.8"652"(497.11)

Archaeological Institute, Belgrade

ID: 195901708

Živko Mikić,

Original research article

University of Belgrade,

Faculty of Philosophy, Belgrade

zmikic@f.bg.ac.rs

Received: June 04, 2011

Accepted: September 05, 2011

\title{
RESULTS OF THE ARCHAEOLOGICAL-ANTHROPOLOGICAL STUDY OF THE MASS BURIAL AT VIMINACIUM - GRAVE G 2158 - THE PEĆINE NECROPOLIS
}

\begin{abstract}
During the rescue archaeological excavations of the southern Viminacium cemeteries in the seventies and eighties of the 20th century, several thousand graves were excavated. Among them, excavated in 1982, was a mass burial numbered G 2158, in which there were nine individuals. An anthropological study was conducted, which showed that they were exclusively male skeletons, of robust structure, whose individual age was between 20 and 40 years. One reason for a common burial of these individuals, most likely members of the military stationed in Viminacium, could have been a clash which occured near the city. Viminacium was located on the Limes so the buried persons may have been killed in one of many barbarian attacks which often occured during the second half of the 3rd century, due to the turbulent times within the empire.
\end{abstract}

KEY WORDS: VIMINACIUM, NECROPOLIS, LIMES, MASS BURIAL, GRAVE.

\section{INTRODUCTION}

During the rescue archaeological excavation of the southern Viminacium cemeteries, several thousand graves were discovered. Although M. Valtrović identified these cemeteries in his report to the Ministry of Education as far back as 1882, their excavation didn't begin until 1977. The cemeteries were, at that time, endangered by the building activities of the thermo power-plant
Kostolac B. The protective excavation was carried out over the next several years, during which time all sections of the cemeteries were named after modern cadastre units, although all of them actually represented parts of one single Viminacium necropolis (Fig. 1). One of the oldest two, created during the $1^{\text {st }}$ century and used up until the end of the $3^{\text {rd }}$ century, consisting of both cremations and skeletal burials, was situated at the site named Pećine (Zotović 1986). In 1982, in this exact area,

* The article results from the project: IRS - Viminacium, Roman city and military legion camp - research of material and non material culture of inhabitants by using the modern technologies of remote detection, geophysics, GIS, digitalisation and $3 D$ visualisation (no 47018), funded by Ministry of Education, Science and Technological Development of the Republic of Serbia. 


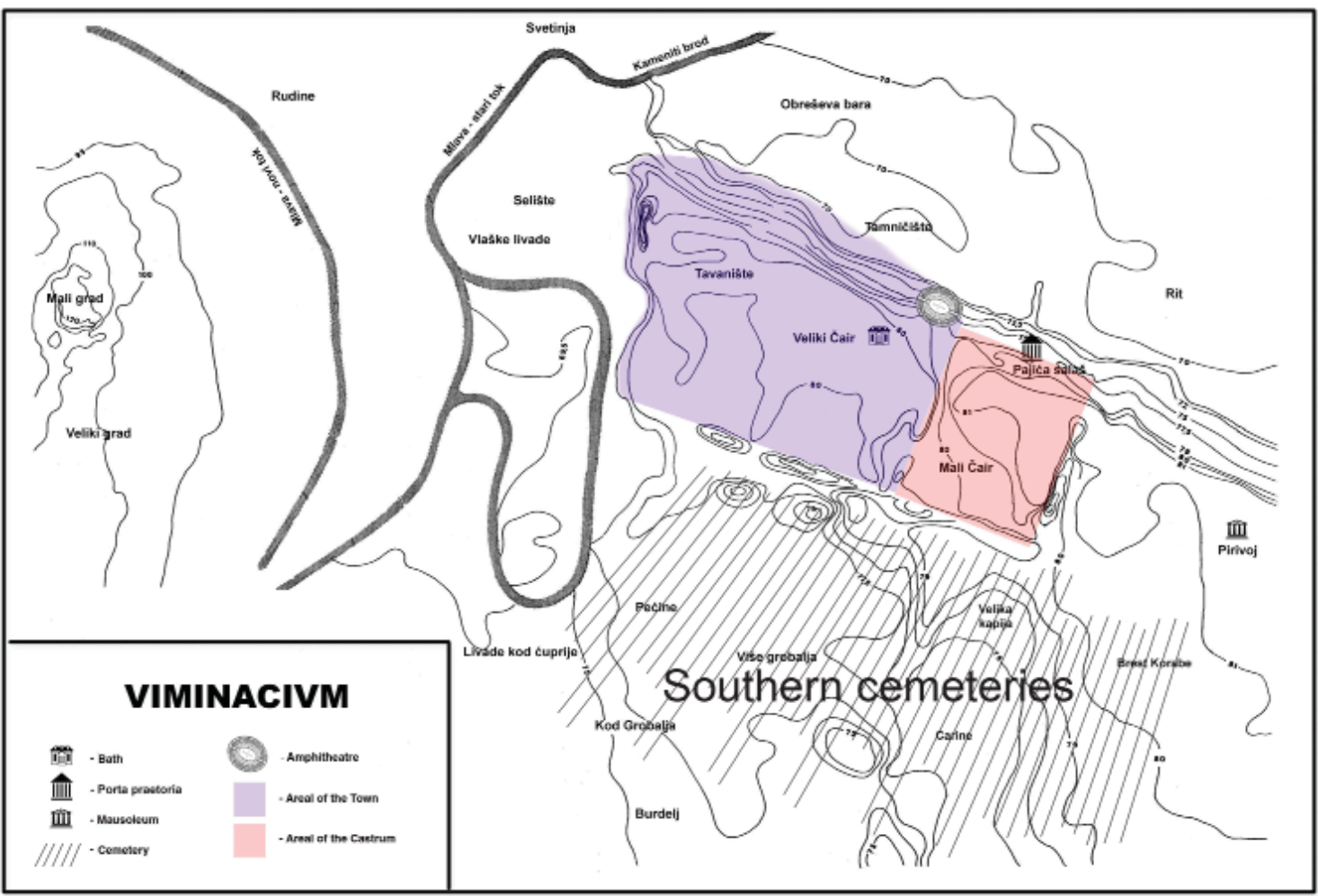

Figure 1. Viminacium - southern necropolis

the mass burial G 2158, consisting of nine individuals, was excavated. Regarding the southern Viminacium cemeteries, 4651 skeletons have been anthropologically examined to date, ranging from the $1^{\text {st }}$ to the $4^{\text {th }}$ century. Among them, 1411 skeletons were discovered in mass burials. It was therefore concluded that one third of all the individuals were buried in mass burials, in which the number of the deceased varied from 2 to 153 (Mikić 1993).

The mass burial G 2158 (sondage 290) was discovered in the part of the cemetery in which burials were extremely densely positioned. In the sondage itself and in its extensions (approx. 200 $\mathrm{m}^{2}$ ), down to a depth of 0.45 to $2.50 \mathrm{~m}, 179$ skeletal and 25 cremated graves were discovered (Fig. 2).

The deceased were buried in two levels (the skeletons are marked from A to I) as follows:

- the first level, down to a depth of $2.20 \mathrm{~m}$, comprising the graves A to C (Fig. 3).

- the second level, down to a depth of 2.50 $\mathrm{m}$, comprising the graves D to I (Fig. 4).
Deceased A - a simply buried deceased, with a brick measuring $43 \times 29 \times 4 \mathrm{~cm}$ as a pillow. A fragmented brick was placed over the face and the shoulders of the deceased. The deceased was extended on its back. The head was lying on the left cheek, facing NE. Its left arm was slightly bent at the elbow and placed next to the body, while the right arm was also bent at the elbow, with the hand placed on the chest. The preserved length of the skeleton measured $1.65 \mathrm{~m}$. It was orientated W-E, with a deviation of $9^{0}$ of its eastern part towards the north. The head and the torso were placed slightly above the pelvis and the legs. The lower legs were placed on the eastern part of the cover of skeleton I, with the right lower leg placed $10 \mathrm{~cm}$ above the upper arm of skeleton $\mathrm{H}$.

Deceased B - was placed to the south of deceased $\mathrm{A}$ and to the north of deceased $\mathrm{C}$. It was positioned lying on its back in an extended position. The arms were bent at the elbows and the right hand was placed on the left side of the pelvis, while the left hand was placed on the right 


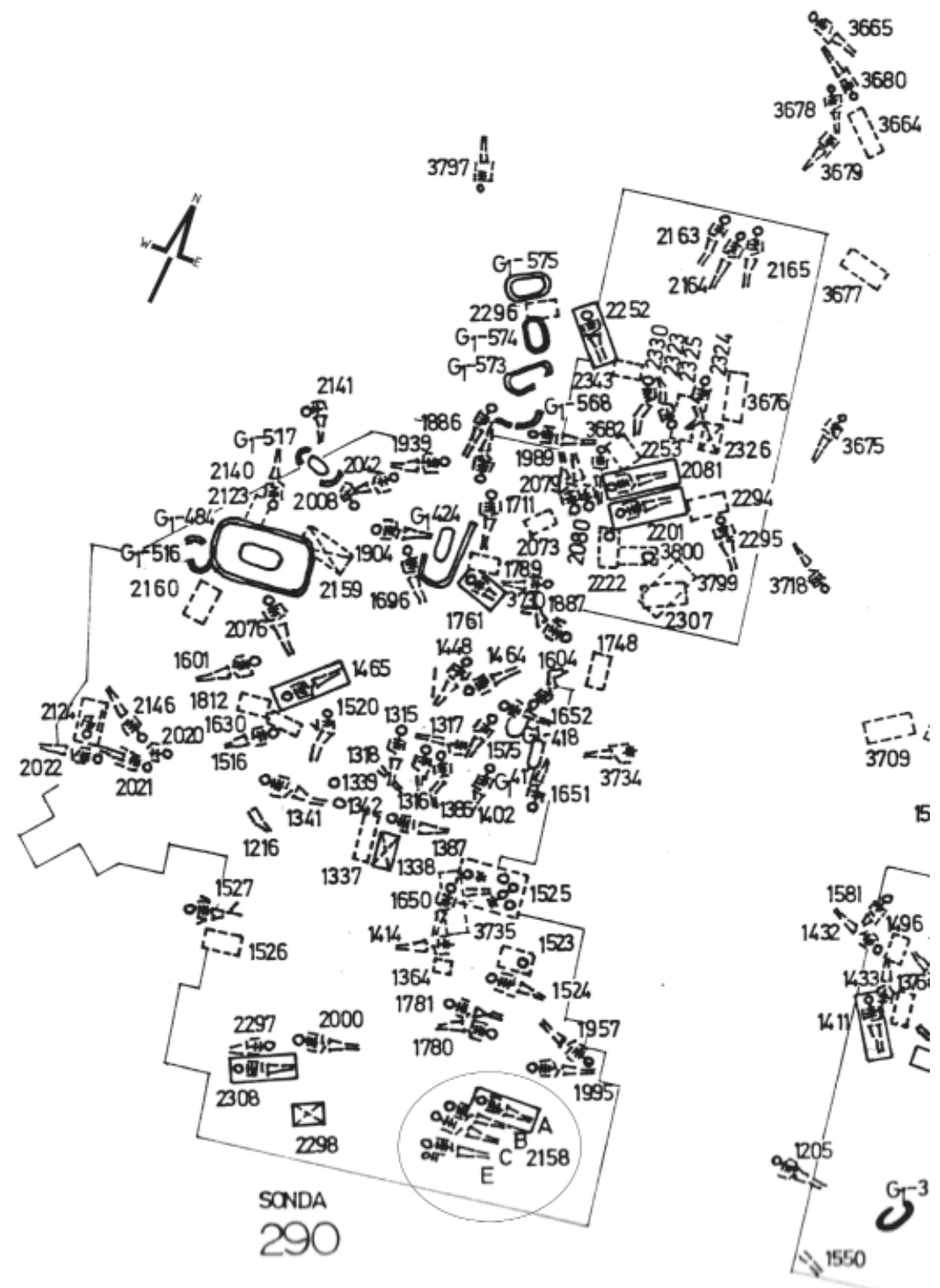

Figure 2. The position of grave G-2158 within the sondage 290

upper arm and the left lower arm of skeleton C. A fragmented brick, also lying on the lower legs of skeleton $\mathrm{C}$, was placed on the lower legs. The preserved length measured $1.54 \mathrm{~m}$. It was orientated W-E, with a deviation of $6^{0}$ of its eastern part towards the south.

Deceased $\mathrm{C}$ - placed lying on its back in an extended position. The arms were bent at the elbows, with both hands placed on the pelvis, right over left. The head was lying on the left cheek, facing NE. The preserved length measured 1.59 m. It was orientated W-E, with a deviation of $8^{0}$ of its eastern part towards the south.

Deceased D - was placed to the north of deceased E. It was placed lying on its back in an extended position. The left arm was stretched next to the body, with the left hand on the left upper leg. The right arm was slightly bent at the elbow, with the hand next to the right upper leg. The left foot was placed on the right one. The head and the torso were positioned slightly above the pelvis and the legs. The preserved length measured 1.47 


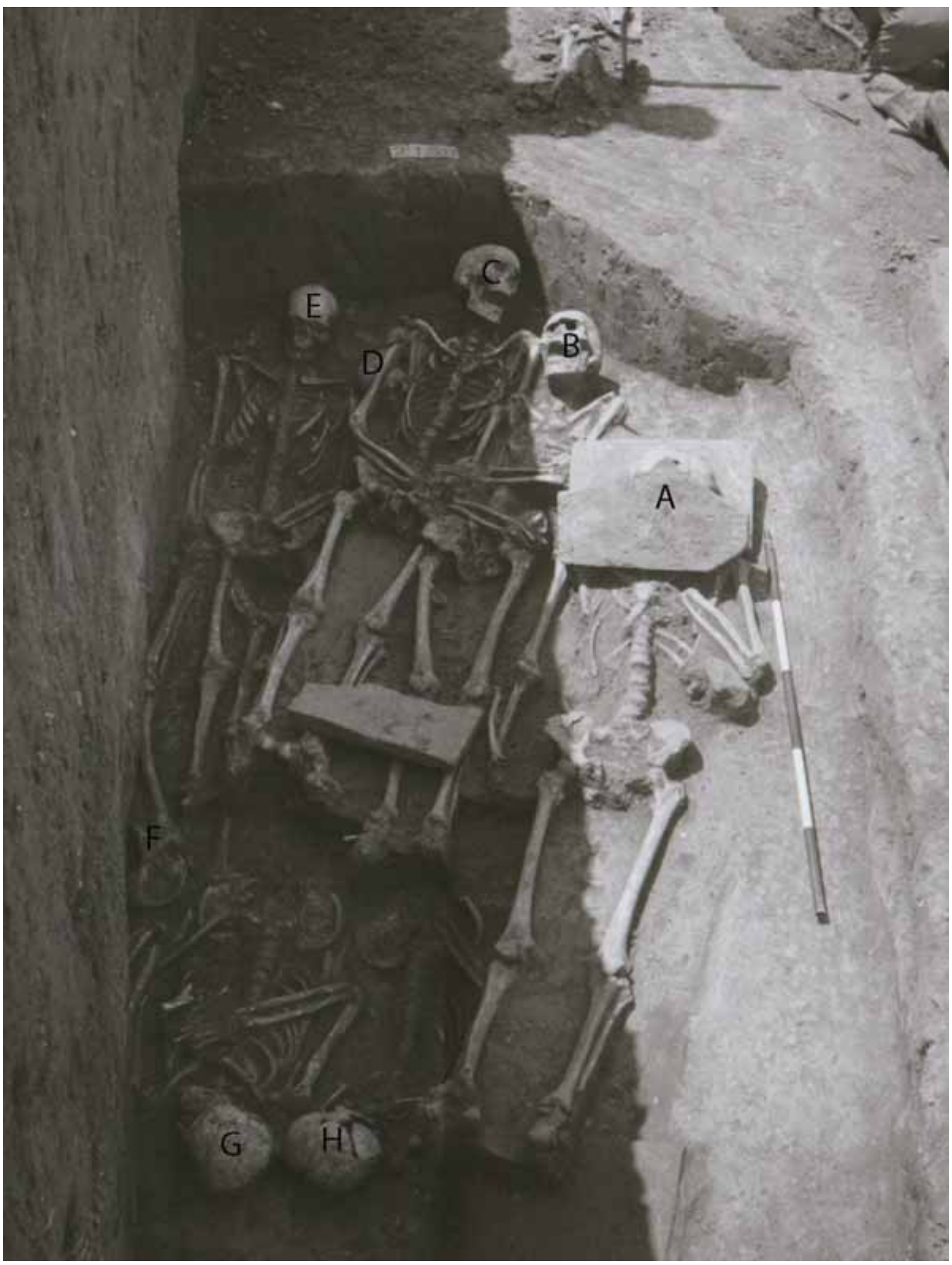

Figure 3. The first burial level - depth $2.20 \mathrm{~m}$, A to C 


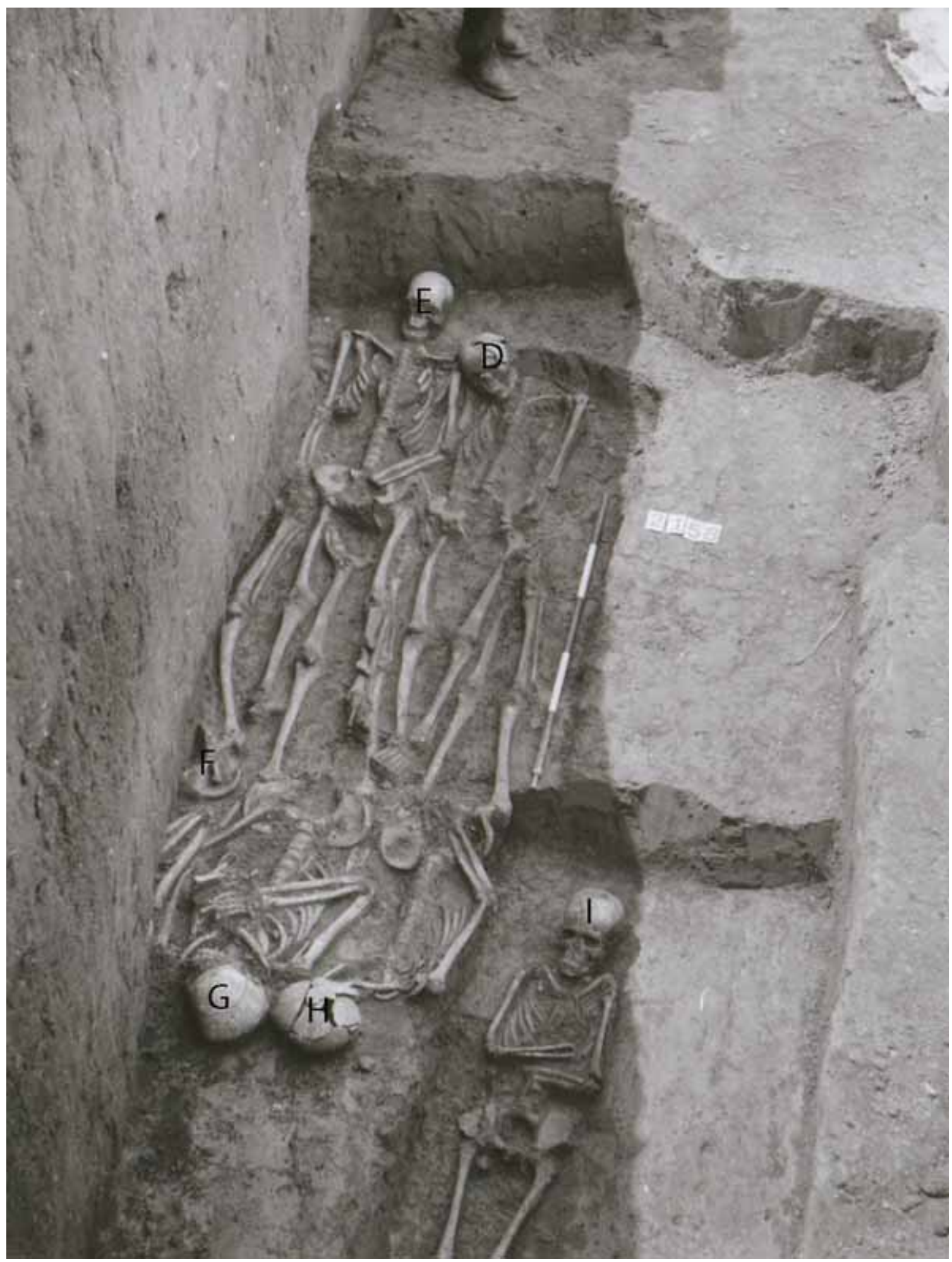

Figure 4. The second burial level - depth $2.50 \mathrm{~m}$, D to I 
m. It was orientated W-E, with a deviation of $16^{0}$ of its eastern part towards the south.

Deceased E - was placed lying on its back in an extended position. The right arm was placed next to the body, with the hand placed on the foot of deceased F. The preserved length measured $1.58 \mathrm{~m}$. It was orientated W-E, with a deviation of $6^{0}$ of its eastern part towards the north.

Deceased F - was placed lying on its back in an extended position. The right arm was bent at the elbow, with the hand placed on the neck. The left arm was placed next to the body, with the hand placed on the left half of the pelvis. The legs were together at the knees and ankles. The preserved length measured $1.66 \mathrm{~m}$. It was orientated E-W, with a deviation of $8^{0}$ of its western part towards the south.

Deceased $\mathrm{G}$ - was placed lying on its back in an extended position. It was between skeletons $\mathrm{F}$ and $\mathrm{H}$. The arms were bent at the elbows, with the left hand lying on the left half of the pelvis and the right arm placed on the chest. The preserved length measured $1.65 \mathrm{~m}$. It was orientated E-W, with a deviation of $14^{\circ}$ of its western part towards the south. On the right temple, a silver Probus coin was found (C 5922).

Deceased $\mathrm{H}$ - was placed lying on its back in an extended position. The head was lying on the left cheek, facing south and touching the skull of the deceased G. The left arm was extended next to the body, with the hand on the left upper leg. The right arm was bent at the elbow, with the hand on the pelvis. The preserved length measured $1.57 \mathrm{~m}$. It was orientated $\mathrm{E}-\mathrm{W}$, with a deviation of $6^{0}$ of its western part towards the south. To the right of the skull, a silver Aurelianus coin was found (C 5923).

Deceased I - buried under a cover consisting of four horizontally placed bricks (each measuring $42 \times 29 \times 4 \mathrm{~cm}$ ). The dimensions of the cover were $1.20 \times 0.42 \mathrm{~m}$. It was orientated W-E, with a deviation of $6^{0}$ of its western part towards the north. The skeleton was discovered at a depth of $2.65 \mathrm{~m}$. The deceased was placed lying on its back in an extended position. The arms were bent at the elbows, with the hands placed on the torso, right over left. The preserved length measured $1.30 \mathrm{~m}$.

The discovery of two coins, dating from the second half of the $3^{\text {rd }}$ century have been used to date the whole burial site to the end of the $3^{\text {rd }}$ century.

The excavation of the skeletons from mass grave G 2158 lasted for a long time, owing to the fact that it was discovered at a level deeper than 2 $\mathrm{m}$ and that it was a specific kind of burial. In addition, the area of sondage 290 was very densely covered with burials and had to be extended several times. After the technical survey, the skeletons were lifted. During this process, it became obvious that their preservation level was varied. This became especially clear during the anthropological analysis. Compared to the in situ situation and to what could be seen in photographs, it was expected that the skeletons would be much better preserved. However, after the initial study and during the anthropological analysis, i.e. after washing and drying, it was obvious that the skulls and the long bones were extremely fragmented. This is why the anthropological research was performed only on skulls 2158/B and 2158/C. They were successfully reconstructed and anthropologically measured. Unfortunately, the post-cranial measurements could not be obtained (apart from some diameters), due to damage caused during the washing of the porous bones. In such a situation, measurements could have been reconstructed; however, this was not acceptable in this case. This is why only the archaeological data obtained in situ were used for measuring corporal height. They could have been used as relative measurements. On the other hand, from a strictly morphological perspective, it can be observed that all of the skeletons were of a robust type, especially their post-cranial skeletons and long bones.

The anthropological content of this grave consists of nine individual skeletons. Eight of them showed complete morphological growth of bones and teeth, while the skeleton marked as 2158/I was 
younger than 20 years of age. This is why criteria defined by D. Ferembach, I. Schwidetzky and M. Stloukal (1980), D. R. Brothwell (1981), C. O. Lovejoy (1985) and J. E. Buikstra and H. D. Ubelaker (1994) were applied. They made it possible to obtain results not only about individual age, but also about gender. The age and gender markers preserved were sufficient and the results obtained can be considered as reliable. It only has to be noted that, while estimating individual age, the maximum age was stated in order to avoid future errors caused by the preservation degree of the skeletons from this Viminacium mass grave.

As already mentioned, the preservation degree made it possible to reconstruct and anthropologically examine only two skulls: numbers 2158/B and 2158/C. The anthropological measuring was performed according to the standardised methodological principles defined by R. Martin (1928), i.e. R. Martin and K. Saller (1957), later re-defined by W. M. Bass (1995).

Basic paleo-demographic results obtained by the anthropological research of mass grave 2158 are shown in table 1. It turned out that in this grave only male individuals were buried. Their life spans varied from 20 to 40 years. An exception is the skeleton marked 2158/I. Contrary to other skeletons, the closing of the epiphysis edges of the long bones and the growth of permanent teeth was not yet complete. After considering the aforementioned literature and applying the criteria, it was estimated that this individual was between 15 and 19 years of age at the moment of death. The gender characteristics clearly showed that this individual was a male. Still, the position of this skeleton within the grave 2158 was specific because it was placed at a distance from the mass burial and this raised the question as to whether it belonged to the mass burial or was, in fact, an individual burial from an earlier time.

Table 2 shows the primary anthropological measurements for skull numbers 2158/B and $2158 / C$, which were the only two successfully reconstructed, connected with their anatomicalmorphological units and later studied in detail. They are illustrated (Fig. 5; Fig. 6) in standardised anthropological projections (Norma lateralis, facialis, verticalis, and occipitalis). While observing the measured values in table 2 , it can be immediately noticed that the two skulls are completely different in their morphostructures. Skull number 2158/B has a short, wide and high cerebral portion, as well as a wide and fully featured face. The basic cranial index (length-width) measures 84.57, indicating that it belongs to the highly brachycrane category.

Unlike the above mentioned skull, skull $2158 / \mathrm{C}$ has a cranial index value of 71.79 . This shows that it belongs to the dolichocephalic category. Additionally, its cerebral part is extremely long, with an average width and height. The face was obviously narrow, although the bisygomatic width is missing (see table 2 and Fig. 6) and it can be said that it was almost fully featured.

In the context of the whole burial, these two completely differently modelled skulls, and therefore morphologically different individuals, could not have been buried in the same grave based on their genetic connection. They were placed within the same grave due to some other criteria, which we will try to reconstruct here.

Skull number 2158/B is unique not only because of its morpho-structure, but also because of a traumatic injury on the back of the head (Fig. 7), which was certainly the causa mortis. More specifically, on the occipital bone, there is an irregular circular trace with a diameter of about $4 \mathrm{~cm}$, showing that the protuberantia occipitalis externa and the area around it were removed with a cut (Steinbeck 1976). More details regarding this injury are given in the paper by N. Korać and I. Mikić (2011). It is clear that one is dealing here with a cut made by a heavy sharp blade, which also removed not only a part of the os occipitale, but most likely the soft part of the back of the head too.

Contrary to the aforementioned paper by 

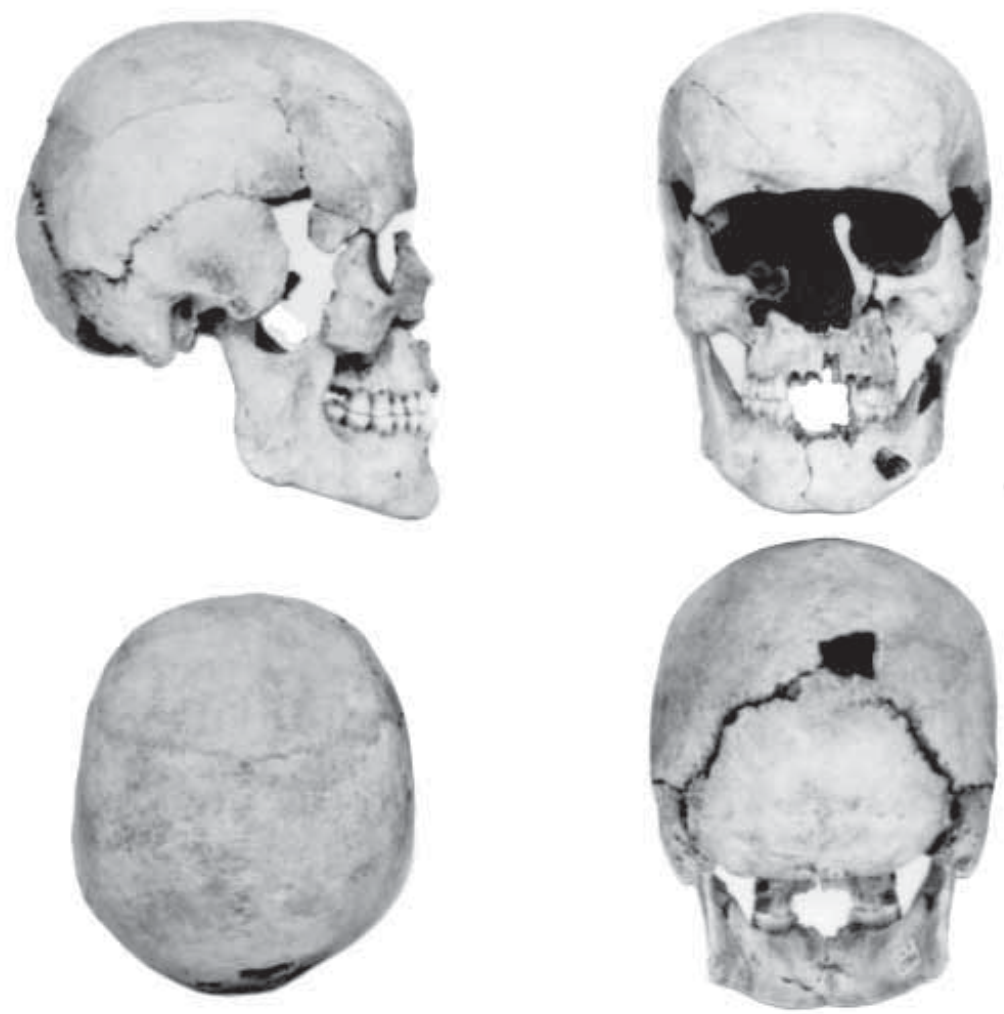

Figure 5 Anthropological projections of the scull 2158B
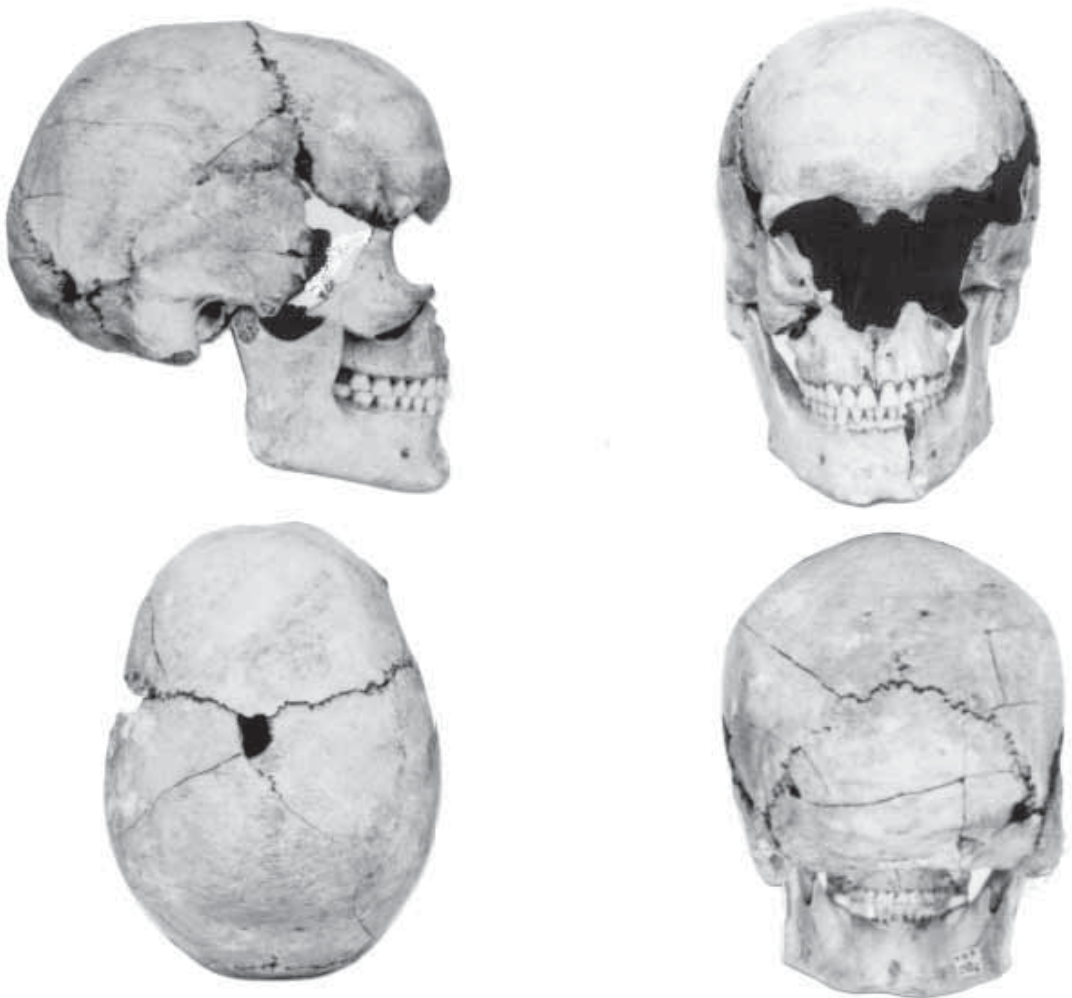

Figure 6. Anthropological projections of the scull $2158 \mathrm{C}$ 
N. Korać and I. Mikić, this injury will be observed in a different context, i.e. as an element of mass grave 2158. With the exception of skull number $2158 / C$, which was already shown anthropologically, all of the other skulls were much less preserved and could not be reconstructed. Their preservation level, apart from their appearance in situ, was so low that they could not be put into their anatomic contexts. This is why the find of the injury on skull number $2158 / \mathrm{B}$ is very rare in the whole of Viminacium.

The extreme fragmentary preservation of all the skeletons from this grave, i.e. the lack of skull and post cranial parts, reduced the number of anthropological elements necessary for an analysis. This refers especially to anthropometry, dentition, pathology and factors of muscular stress. A question arises about the cause of death for the individual 2158/B, which was a trauma, and for other skeletons from the same grave. In other words, what kind of connection existed between all of these men buried within grave 2158, even though, as previously stated, it was not of a genetic nature?

There were attempts to interpret secondary burials at Viminacium, although only from an anthropological perspective (e.g. Mikić 1988). Unfortunately, they did not result in any expected complete results. This is why, within the analysis of mass grave 2158, both archaeological and anthropological data were combined in order to record as many of its features as possible.

This paper represents the first results of an archaeological-anthropological analysis of a mass grave, similar to those noticed in greater numbers in Viminacium. Grave number 2158 from the Pećine necropolis contained nine skeletons, eight of which were individual skeletons belonging to the mass burial and one from and earlier burial, all of which were primarily buried. As a result of

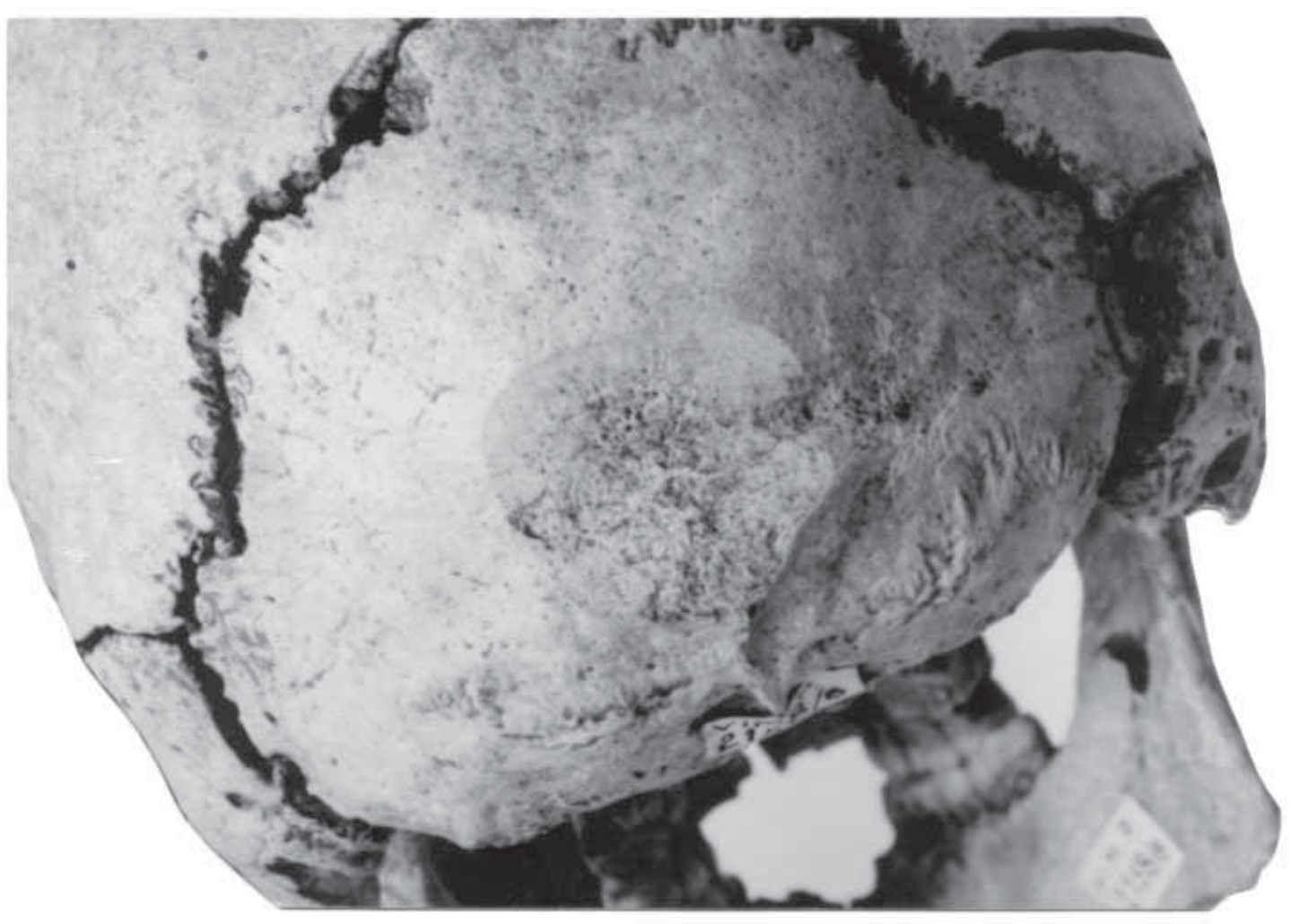

Figure 7. Injury on the back of the skull 2158/B 


\begin{tabular}{|c|c|c|}
\hline Skeleton number 2158 & Sex & Age \\
\hline A & male & up to 30 years * \\
\hline B & male & up to 40 years \\
\hline C & male & $30 / 35$ years \\
\hline D & male & $30 / 35$ years \\
\hline E & male & up to 40 years \\
\hline F & male & $35 / 40$ years \\
\hline G & male & $35 / 40$ years \\
\hline H & male & up to 40 years \\
\hline I & male & $15 / 19$ years \\
\hline
\end{tabular}

Table 1: Viminacium/Pećine - grave number 2158 - distribution of gender and individual age *according to the preservation level, the maximum life-length is presented

\begin{tabular}{|c|c|c|}
\hline Skull number & $2158 / \mathrm{B}$ & $2158 / \mathrm{C}$ \\
\hline Sex & male & male \\
\hline Age & do 40 years & $30 / 35$ years \\
\hline Maximum skull length & $175 \mathrm{~mm}$ & $195 \mathrm{~mm}$ \\
\hline Maximum skull width & 148 & 140 \\
\hline Minimum forehead width & 105 & 101 \\
\hline Maximum skull height & --- & --- \\
\hline Skull height up to the ears (PO-B) & 121 & 119 \\
\hline Bisgomatic width & 130 & --- \\
\hline Height of the lower face & $(74)$ & 72 \\
\hline Eye-socket width & $(37)$ & -- \\
\hline Eye-socket height & $(33)$ & -- \\
\hline Width of the nose opening & --- & $(23)$ \\
\hline Nasal height & --- & 52 \\
\hline Mandibula width & 107 & 99 \\
\hline Longitudinal-latitudinal index & 84.57 & 71.79 \\
\hline
\end{tabular}

Table 2: Viminacium/Pećine - grave number. 2158 - primary skull measurements and basic index ( ) - mark for anthropological measure gained through reconstruction

comprehensive documentation, details about the burial, such as the diametric positioning in this mass grave as well as other chronological-archaeological data, have already been given.

The anthropological analysis showed that one was dealing here only with male skeletons displaying robust features, especially those of the post cranial parts, and strong muscles, which indicates strong physical features. Their life spans varied from 20 to 40 years. Moreover, on one of the skeletons a direct causa mortis was observed in the form of a cut on the back of the head, made with a sharp blade, causing immediate death. The two best preserved (and illustrated) skulls belong 
to different anthropo-morphological types, indicating that no genetic connection between the individuals existed.

After summarising the data and attempting to understand the reasons for a common burial, it all suggests that this was a burial of soldiers stationed in Viminacium. These individuals could have died in a fight near the city. Viminacium was built directly on the border (the Limes), so they could have been killed in a barbarian raid or in a battle, which were numerous during the second half of the $3^{\text {rd }}$ century due to the history of this part of the empire. Nevertheless, they were killed nearby after which the bodies were collected and buried in one of the Viminacium cemeteries. It is certain that this mass grave at Viminacium will be subject to more complex interpretation after the analyses of other, similar, mass graves has been completed.

\section{BIBLIOGRAPHY}

\section{Bass, W. M. 1995}

Human Osteology, A Laboratory and Field Manual, Columbia: Missouri Archaeological Society.

Ferembach D., Schwidetzky I. and Stloukal M., 1980

Recommendation for Age and Sex diagnosis of Skeletons, Journal of Human Evolution 7, 517549.

\section{Brothwell, D. 1981}

Digging up Bones, London: British Museum (Natural History) and Oxford: Oxford University Press.

\section{Buikstra, J. E. and Uberlaken, D. H., 1994}

Standards for Data Collection from Human Skeletal Remains: Proceedings of a Seminar at the Field Museum of Natural History (Arkansas Archaeological Report Research Series, No. 44, Fayetteville, Arkansas: Arkansas Archaeological Survey.

\section{Lovejoy, C.O. 1985}

Dental Wear in the Libben Population: Its Functional Pattern and Role in the Determination of Adult Skeletal Age at Death, American Journal of Physical Anthropology 68, 47-56.

\section{Martin, R. and Saller, K. 1957}

Lehrbuch der Anthropologie in systematischer Darstellung. 3. Auflage, Stuttgart.

\section{Martin, R. 1928}

Lehrbuch der Anthropologie in systematischer Darstellung. 1. Auflage, Jena.

\section{Korać, M. and Mikić, Ž. 2011}

Nalazi Causa mortis na skeletima iz Viminacijuma u kontekstu otkrića amfiteatra, Arheologija i prirodne nauke 7, Beograd 2011.

\section{Steinbeck, R. T. 1976}

Paleopathological Diagnosis and Interpretation: Bone Diseases in Ancient. Human Populations, Springfield: Charles C. Thomas.

\section{Mikić, Ž. 1988}

Antropološki aspekti tumačenja nekih oblika sahrana na antičkom Viminacijumu, Godišnjak XXVI/24 Centra za balkanološka ispitivanja AN$U B i H$, Sarajevo, 121-145.

\section{Mikić, Ž. 1993}

Viminacijum - antropološki pregled grupnih grobova rimskog perioda (I) i prikaz nekropola iz perioda velike seobe naroda (II), Saopštenja XXV, Beograd, 197-207.

\section{Zotović, Lj. 1986.}

Južne nekropole Viminaciuma i pogrebni običaji, Viminacium 1, Požarevac, 41-59. 


\section{REZIME}

REZULTATI ARHEOLOŠKOANTROPOLOŠKIH STUDIJA O GRUPNOM SAHRANJIVANJU U VIMINACIJUMU - GROB G 2158 - NEKROPOLA NA LOKALITETU PEĆINE

KLJUČNE REČI: VIMINACIUM, NEKROPOLA, LIMES, GRUPNO SAHRANJIVANJE, GROB.

Tokom zaštitnih arheoloških iskopavanja južnih nekropola Viminacijuma istraženo je više hiljada grobova. Iako je ove nekropole identifikovao još M. Valtrović u svom izveštaju Ministarstvu prosvete iz 1882. godine, arheološka istraživanja počinju tek 1977. godine i to zbog ugroženosti nalazišta izgradnjom termoelektrane Kostolac B. Zaštitna arheološka iskopavanja trajala su nekoliko sledećih godina kada su identifikovane nekropole koje su dobile ime po savremenim katastarskim jedinicama, a ustvari pripadaju jedinstvenoj viminacijumskoj nekropoli (Sl. 1). Jedna od dve najstarije, formirana oko sredine I veka, a korišćena do kraja III, sa paralelnim sahranama kremiranih i inhumiranih pokojnika, bila je locirana na lokalitetu Pećine (Zotović 1986). Upravo je na tom prostoru godine 1982. istražena grupna sahrana pod brojem G 2158 sa devet individua. Grupna sahrana, grob G 2158 (sonda 290), nađen je u delu nekropole sa izuzetno gustim sahranama tako da je u samoj sondi i u njenim proširenjima (cca $200 \mathrm{~m}^{2}$ ) od dubine 0,45 do 2,50 m nađeno 179 grobova sa inhumacijom i 25 sa kremacijom (Sl. 2). Pokojnici su bili sahranjeni u dva nivoa (skeleti su obeleženi slovima od A do I) i to:

- prvi nivo na dubini 2,20 m koji obuhvata grobove od A do C (Sl. 3).

- drugi nivo na dubini 2,50 m koji obuhvata grobove od D do I (Sl. 4).

Ovaj prilog predstavlja prve rezultate arheološko-antropološke analize jednog grupnog groba, koji su na nekropoli Viminacijuma zabeleženi u većem broju. Grob broj 2158 sa nekropole Pećine sadržavao je devet, odnosno osam individualnih skeleta, primarno sahranjenih.

Antropološka analiza je pokazala da se radi isključivo o muškim skeletima robustne građe posebno postkranijalnih delova, sa jakim hvatištima mišića, što govori o njihovoj izraženoj muskuloznosti, odnosno o jakoj fizičkoj građi. Životni vek im se kretao između 20 i 40 godina. $\mathrm{Na}$ jednom od ovih skeleta konstatovan je direktan Causa mortis. Radi se zapravo o sekotini zatiljačnog dela lobanje oštrim oružjem, koje je izazvalo trenutnu smrt. Dve najbolje očuvane (i ilustrovane) lobanje pripadaju dijametralno različitim antropo-morfološkim tipovima, što znači da ih nikakva genetska povezanost nije mogla dovesti u zajednički grob.

Kada sumiramo sve dobijene podatke $\mathrm{i}$ pokušamo da razjasnimo razloge zajedničke sahrane, čini nam se da sve ukazuje na sahranu pripadnika vojske stacionirane u Viminacijumu. Ovi pojedinci su mogli "nastradati" u okršaju sasvim blizu grada. Naime, Viminacijum je bio na samom Limesu i mogli su poginuti u upadu varvara ili čarkama na granici kojih je u drugoj polovini III veka sigurno bilo u znatnom broju usled turbulentnog stanja u Carstvu. U svakom slučaju, stradali su u određenim sukobima u blizini nakon kojih su njihova tela mogla biti pokupljena, a potom i zajedno sahranjena na viminacijumskoj nekropoli. Svakako da će ova grupna sahrana na Viminacijumu biti još kompleksije interpretirana kada se na sličan način budu analizirali jos neki slučajevi zajedničkih primarnih sahrana, za razliku od sekundarnih. 